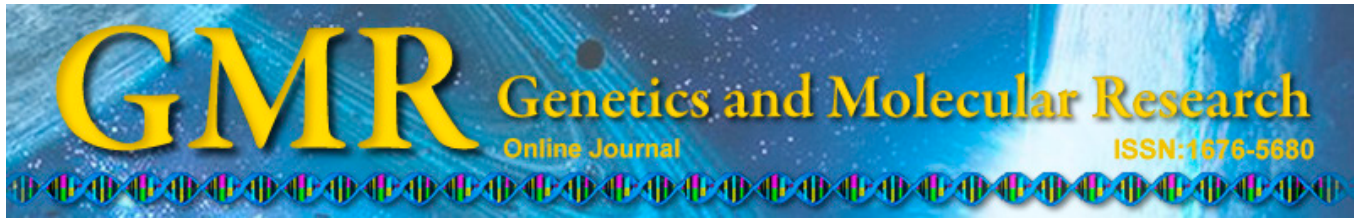

\title{
Use of elephant grass for energy production in Campos dos Goytacazes-RJ, Brazil
}

\author{
R.F. Daher ${ }^{1}$, L.B. Souza1 ${ }^{1}$, G.A. Gravina ${ }^{1}$, J.C. Machado ${ }^{2}$, \\ H.C.C. Ramos ${ }^{1}$, V.Q.R. Silva ${ }^{3}$, B.R.S. Menezes ${ }^{1}$, L.S.A. Schneider ${ }^{1}$, \\ M.L.F. Oliveira ${ }^{1}$ and R.D. Gottardo ${ }^{1}$ \\ ${ }^{1}$ Universidade Estadual do Norte Fluminense Darcy Ribeiro, \\ Campos dos Goytacazes, RJ, Brasil \\ ${ }^{2}$ Embrapa Gado de Leite, Juiz de Fora, MG, Brasil \\ ${ }^{3}$ Embrapa Agrossilvipastoril, Sinop, MT, Brasil \\ Corresponding author: R.F. Daher \\ E-mail: rogdaher@uenf.br
}

Genet. Mol. Res. 13 (4): 10898-10908 (2014)

Received March 19, 2014

Accepted August 4, 2014

Published December 19, 2014

DOI http://dx.doi.org/10.4238/2014.December.19.11

\begin{abstract}
Elephant grass is a tropical forage plant widely distributed throughout Brazil. It was first exclusively used in the livestock sector as cattle feed. The grass is characterized by its high productivity and photosynthetic capacity and is considered as an alternative source of renewable energy. Here, we estimated the general combining ability of the parents and specific combining ability of the hybrids based on morpho-agronomic biomass-quality traits. The experiment was conducted in a randomized block design with 3 replicates. The diallel was composed of 16 hybrids and 2 groups of genitors. In the diallel analysis of variance, we observed a significant difference among treatments. A significant difference was observed among genitors for dry matter production (DMP). For the general combining ability of group 1, the traits leaf blade width, DMP, height, percentage of neutral detergent fiber, percentage of hemicellulose, percentage of lignin, percentage of acid detergent fiber, and percentage of cellulose were significant. For the estimates of general combining ability of DMP, parents Porto Rico
\end{abstract}


534-B, Vruckwona, Taiwan A-146, and Mercker S. E. A. were 0.4748, $3.2819,1.1659$, and 0.4317 . The parents of Mercker S. E. A. and Porto Rico 534-B produced the highest percentage of detergent fiber and percentage of lignin with values of 0.1482 and 0.0856 . Thus, parents Vruckwona, Porto Rico 534-B, and Taiwan A-146 are promising for integration into breeding programs. The best hybrid combinations for DMP were $1 \times 5,1 \times 8,2 \times 6,3 \times 7$, and $4 \times 5$.

Key words: Additive effect; Biomass; Diallel; Hybrids; Quality traits

\section{INTRODUCTION}

Significant attention has been given to environmental preservation, including the preservation of water soil, air, fauna, and flora. It is widely known that new energy alternatives that promote environmental preservation are urgently required.

Various energy sources have been used in Brazil, such as eucalypt and sugarcane (Osava, 2007). However, the elephant grass, a plant that has been recently studied for energy production, has also considered to be highly promising for this purpose (Urquiaga et al., 2005; Osava, 2007; Silva et al., 2010).

The grass was relocated to Brazil from Africa (Bennet, 1976) to be used as pasture, mainly for dairy cattle farming (Osava, 2007). Its main advantages relative to other sources include fast growth and resistance to unfavorable climatic conditions such as drought and low temperatures (Freitas et al., 2000; Queiroz Filho et al., 2000; Santos et al., 2001; Silva et al., 2002). In addition, it can generate large amounts of biomass.

Several studies have been carried out at institutions such as Embrapa, Instituto de Pesquisas Tecnológicas (SP), Universidade Federal Rural do Rio de Janeiro (UFRRJ), and Universidade Estadual do Norte Fluminense-UENF (RJ) to examine the potential uses of plant biomass. These studies identified genotypes with adequate profiles for biomass production. Plants used for biomass should have the following characteristics: high tillering, as greater productivity coincides with a larger number of tillers per area, tall plant height (Ferraris, 1979), large stem diameter, wide leaves, high contents of fiber (Morais et al., 2009), cellulose and lignin, and high calorific power.

Various studies have been conducted, including the examination of genetic breeding, such as at Universidade Federal do Norte Fluminense, by Rossi (2010), Silva (2011), and de Lima et al. (2011). Breeding of elephant grass has been conducted relatively recently compared with other grain-yielding species, for which numerous studies have been conducted (Pereira et al., 2001). The potential of the germplasm in elephant grass has not thoroughly examined. Thus, we examined the potential for rapid gains through breeding.

In this study, we estimated the general combining ability (GCA) of parents and specific combining ability (SCA) of hybrids based on morpho-agronomic traits and biomass quality.

\section{MATERIAL AND METHODS}

The experiment was conducted at the State Center for Research on Agro-Energy and Waste Utilization of PESAGRO, located in the municipality of Campos dos Goytacazes-RJ, Brazil (latitude $21^{\circ} 19^{\prime} 23^{\prime \prime} \mathrm{S}$, longitude $41^{\circ} 19^{\prime} 40^{\prime \prime} \mathrm{W}$, and altitude of 20-30 m). 
The climate in the region is tropical with dry winter season according to Köppen classification. The experimental design used randomized blocks with 3 replicates. The plot was composed of a 4-m row with rows spaced $1.5 \mathrm{~m}$ apart and $1 \mathrm{~m}$ within the rows. Each block was composed of 25 treatments ( 16 hybrids, 8 parents, and 1 control).

Planting was performed in May 2010 using stakes, with the basal portion of plants in contact with the apical region of the following seedlings, distributed into 10-cm-deep ridges. At planting, $100 \mathrm{~kg} / \mathrm{ha}$ single superphosphate were incorporated. Irrigation was provided only during plant emergence and, 50 days after planting, a fertilization procedure was applied, with $25 \mathrm{~kg} / \mathrm{ha}$ of ammonium sulfate and potassium chloride.

After the establishment phase, all genotypes were cut near the soil level (plot leveling) on December 17, 2010, followed by top-dressing of 25/ha ammonium sulfate and potassium chloride. In the plots with failures of plant emergence, planting was repeated.

The 1st cut was performed on August 25, 2011 (36 weeks after plot leveling cut-dry season), the 2nd cut on April 16, 2012 (36 weeks after the 1st cut-rainy season), and the 3rd cut on September 25, 2012 (23 weeks after the 2nd period-dry season).

Two groups of parents of elephant grass were used. Group 1 included 4 male parents: Taiwan A-144 (P1), Vruckwona (P2), Pusa Napier No. 2 (P3), and Porto Rico 534-B (P4). Group 2 was composed of 4 female parents, including Mercker Santa Rita (P5), Taiwan A-146 (P6), Mercker S. E. A. (P7), and Napier No. 2 (P8). Accession BAG-86 was used as a control.

The 16 hybrid combinations obtained from the diallel crosses shown in Table 1 and included H1 (1 x 5), H2 (1 x 6), H3 (1 x 7), H4 (1 x 8), H5 (2 x 5), H6 (2 x 6), H7 (2 x 7), H8 (2 x 8), H9 (3 x 5), H10 (3 x 6), H11 (3 x 7), H12 (3 x 8), H13 (4 x 5), H14 (4 x 6), $\mathrm{H} 15$ ( 4 x 7), and H16 (4 x 8).

Traits were evaluated in samples from the aerial region of the plants and divided into morpho-agronomic and biomass-quality. For each cut, the following morpho-agronomic traits were evaluated: plant height (HGT), in meters, measured from the soil to the curvature of the last completely expanded leaf; stem diameter (SD), in mm, measured $10 \mathrm{~cm}$ above the soil level; leaf blade width, in $\mathrm{cm}$, measured with a graduated ruler and obtained from 3 measurements in each replicate; number of tillers (NT), per linear meter: the count was made in $1.0 \mathrm{~m}$ within the rows, disregarding the extremities resulting from sprouting failures; and total green matter production, in $\mathrm{t} / \mathrm{ha}$, for which the fresh biomass of the plots was weighed. Immediately after this, 1 tiller (a subsample) was dried in an oven at $65^{\circ} \mathrm{C}$ for $72 \mathrm{~h}$ until a constant weight was reached (air-dried sample). The dry material (leaf and stem) was ground in a Wiley mill with a 1-mm mesh sieve and conditioned in a plastic bottle. The samples were dried again in an oven at $105^{\circ} \mathrm{C}$ for $12 \mathrm{~h}$ (oven-dried sample). The percentage of dry matter (\%DM) was estimated as the product of the air-dried sample and oven-dried sample, and total dry matter production, in $\mathrm{t} / \mathrm{ha}$.

Biomass quality traits for the samples from the first and second cuts were evaluated, including percentage of ash (\%ASH), estimated as the ratio of the weight of the sample dried in a muffle furnace at $600^{\circ} \mathrm{C}$ for $15 \mathrm{~h}$ and the weight of the final dry matter (Silva et al., 2002); percentage of neutral detergent fiber (\%NDF); percentage of acid detergent fiber (\%ADF); percentage of cellulose (\%CEL); percentage of hemicellulose, estimated as the differences obtained between NDF and ADF; and percentage of lignin (\%LIG).

The percentages of NDF, ADF, CEL, and LIG were analyzed at the Laboratory of Food Analysis of Embrapa Gado de Leite using near-infrared spectroscopy. All analyses were performed based on the whole plant. 
For diallel analysis, we adopted the method of Griffing (1956), with adaptations for the partial diallels proposed by Geraldi and Miranda Filho (1988). We first performed joint variance analysis of the cuts using the F test to evaluate combining ability. Next, the effects of the GCA of each parent and of the specific combining ability of each hybrid were estimated. Analyses were performed using GENES computer software (Cruz, 2013).

Table 1. Scheme of partial diallel crosses with 8 parents.

\begin{tabular}{lcccc}
\hline Group 2 (female genitors) & \multicolumn{3}{c}{ Group 1 (male genitors) } \\
\cline { 2 - 5 } & Taiwan A-144 (P1) & Vruckwona (P2) & Pusa Napier N 2 (P3) & Porto Rico 534-B (P4) \\
\hline Mercker Santa Rita (P5) & H1 & H5 & H9 & H13 \\
Taiwan A-146 (P6) & H2 & H6 & H10 & H14 \\
Mercker S. E. A. (P7) & H3 & H7 & H12 & H15 \\
Napier N 2 2 (P8) & H4 & H8 & \\
\hline
\end{tabular}

\section{RESULTS}

The results of the diallel analysis of variance with the estimates for the mean squares of the treatments in the groups (Group 1: male parents x Group 2: female parents), GCA of each group, and SCA of the morpho-agronomic and biomass-quality traits are shown in Table 2.

Table 2. Summary of diallel analysis of variance of the combining ability, with the decomposition of the sum of squares of the genotypes (treatments) involving the 16 hybrids resulting from the partial diallel crosses and the 8 elephant grass parents for the morpho-agronomic traits based on 3 cuts and for biomass-quality traits based on 2 cuts. Campos dos Goytacazes, RJ. 2011/2012.

\begin{tabular}{|c|c|c|c|c|c|c|c|c|c|c|c|c|c|}
\hline \multirow[t]{2}{*}{$\mathrm{DF}$} & \multicolumn{13}{|c|}{ Mean squares } \\
\hline & GL & HGT & SD & LBW & NT & DMP & $\% \mathrm{DM}$ & $\%$ ASH & $\% \mathrm{NDF}$ & $\% \mathrm{ADF}$ & $\% \mathrm{CEL}$ & $\%$ HEM & $\% \mathrm{LIG}$ \\
\hline 10 & 23 & $0.262 * *$ & $8.607 * *$ & $0.718^{* *}$ & $423.308^{\mathrm{ns}}$ & $213.579^{*}$ & $30.884 * *$ & $1.158 *$ & $6.845^{* *}$ & $8.517 * *$ & $5.082 * *$ & $1.055^{\mathrm{ns}}$ & $1.193^{*}$ \\
\hline Groups & 1 & $1.402 * *$ & $33.577 * *$ & $0.161^{\mathrm{ns}}$ & $98.750^{\mathrm{ns}}$ & $524.739 *$ & $4.025^{\mathrm{ns}}$ & $2.405^{\mathrm{ns}}$ & $0.565^{\mathrm{ns}}$ & $0.121^{\mathrm{ns}}$ & $0.538^{\mathrm{ns}}$ & $0.414^{\mathrm{ns}}$ & $0.116^{\mathrm{ns}}$ \\
\hline GCA (Group I) & 3 & $0.323^{*}$ & $3.472^{\mathrm{ns}}$ & $0.830^{* *} *$ & $485.262^{\mathrm{ns}}$ & $524.233 * *$ & $17.243^{\mathrm{ns}}$ & $0.752^{\mathrm{ns}}$ & $13.834 * *$ & $15.041 *$ & $6.465^{*}$ & $2.784 * *$ & $2.853 * *$ \\
\hline GCA (Group II) & 3 & 0.03 & 0.5 & $0.254^{\mathrm{ns}}$ & 92.8 & $68.742^{\mathrm{ns}}$ & $38.604^{*}$ & $0.471^{\mathrm{ns}}$ & $5.969^{\text {ns }}$ & $8.160^{\text {ns }}$ & $3.632^{\mathrm{ns}}$ & $0.696^{\mathrm{ns}}$ & $1.151^{\mathrm{ns}}$ \\
\hline SCA & 16 & $0.222 *$ & $9.512 * *$ & $0.819^{* *}$ & $493.939 *$ & $163.041^{\mathrm{ns}}$ & $33.673 * *$ & $1.284 *$ & $6.092 *$ & $7.893 *$ & $5.378 * *$ & $0.838^{\mathrm{ns}}$ & $0.957^{\mathrm{ns}}$ \\
\hline Error & 46 & 0.113 & 3.344 & 0.193 & 261.771 & 112.177 & 11.146 & 0.6624 & 2.761 & 3.5618 & 1.5731 & 0.649 & 0.6029 \\
\hline
\end{tabular}

HGT $=$ plant height $(\mathrm{m}) ; \mathrm{SD}=$ stem diameter $(\mathrm{mm}) ; \mathrm{LBW}=$ leaf blade width $(\mathrm{cm}) ; \mathrm{NT}=$ number of tillers per linear meter; $\mathrm{DMP}=$ dry matter production $(\mathrm{t} / \mathrm{ha}) ; \% \mathrm{DM}=$ percentage of dry matter; $\% \mathrm{ASH}=$ percentage of ash; $\% \mathrm{NDF}=$ percentage of neutral detergent fiber; $\% \mathrm{ADF}=$ percentage of acid detergent fiber; $\% \mathrm{CEL}=$ percentage of cellulose; $\% \mathrm{HEM}=$ percentage of hemicellulose; $\% \mathrm{LIG}=$ percentage of lignin. * Significant at 5\% probability; $* *$ significant at the level of $1 \%$ propability; ns = not significant.

For the source of variation treatments, we observed a significant difference in the $\mathrm{F}$ test at the 1 and $5 \%$ of probability levels for nearly all traits, except for NT and \%HEM, which were not significant, indicating no variability among the genotypes studied.

In the source of variation groups, among the morpho-agronomic traits, we observed significance at $1 \%$ probability for only HGT and SD and at 5\% for DMP. For biomass quality, no significant differences were detected in groups.

Among the morpho-agronomic characteristics, the mean squares of the GCA of group 1 were significant at $1 \%$ of probability only for the traits LL and DMP; the HGT trait was significant at the level of $5 \%$ of probability. Other characteristics such as SD, NT, and \%DM, showed no significant effect. Among the biomass quality traits, \%NDF, \%HEM and \%LIG were significant at $1 \%$, while $\% \mathrm{ADF}$ and $\%$ CEL were significant at $5 \%$ probability. 
For the mean square of GCA in group 2, no significant difference was observed in nearly all evaluated traits, except for $\% \mathrm{DM}$, which was significant at $5 \%$ probability. This indicates that differences exist among the effects of GCA for the parents from both groups, indicating the involvement of additive effects in the control of significant characteristics. The traits SD, NT, \%DM, and \%ASH for group 1 (male parents) showed non-additive genetic effects. In group 2 (female parents), the number of traits with non-additive genetic effects was greater, including HGT, SD, LL, NT, DMP, \%ASH, \%NDF, \%CEL, \%HEM, and \%LIG.

Evaluating the nature and magnitude of genetic effects controlling various quantitative traits is one of the main objectives of plant breeding programs. Therefore, genetic-level studies are essential for investigating the proportions that can be attributed to additive, dominant, and epistatic genetic effects. This evaluation is closely related to the objectives of the breeding programs and these types of genetic actions can be used to explain heterotic expression as well as inbreeding depression (Wilson et al., 1978; Finkner et al., 1981).

For the effect of SCA, the mean squares were significant at $1 \%$ of probability for the $\mathrm{F}$ test for traits SD, LL, \%DM, and \%CEL and at 5\% probability for HGT, NT, \%ASH, \%NDF, and $\% A D F$. However, the traits DMP, \%HEM, and \%LIG were not significant. Thus, for most of the characteristics analyzed, the genetic effect of dominance prevailed.

The estimates of GCA effects of 8 elephant grass parents for morphogenetic traits and biomass quality evaluated in 16 hybrid combinations resulting from partial diallel crosses are presented in Table 3. Parent Porto Rico 534-B showed the highest GCA estimate for HGH: 0.901. Some parents, such as Taiwan A-144, Taiwan A-146, and Mercker S. E. A., showed positive but very low values of $0.009,0.028$, and 0,006 , respectively. In contrast, parents Vruckwona and Pusa Napier No. 2 showed negative values of -0.036 and -0.063 , respectively.

Table 3. Estimates of the effects of the general combining ability of groups 1 and 2 (gi and $\mathrm{g}^{\prime} \mathrm{j}$ ) of 8 genotypes of elephant grass for the morpho-agronomic and biomass-quality traits, assessed in 16 hybrid combinations resulting from the partial diallel crosses. Campos dos Goytacazes, RJ. 2011/2012.

\begin{tabular}{|c|c|c|c|c|c|c|c|c|c|c|c|c|}
\hline \multirow[t]{2}{*}{ Genitors } & \multicolumn{11}{|c|}{ Characteristics } & \multirow[b]{2}{*}{$\%$ LIG } \\
\hline & HGT & SD & LBW & NT & DMP & $\% \mathrm{DM}$ & $\%$ ASH & $\% \mathrm{NDF}$ & $\% \mathrm{ADF}$ & $\%$ CEL & $\%$ HEM & \\
\hline Taiwan A-144 (P1) & 0.009 & -0.316 & -0.060 & -0.530 & -0.502 & 0.347 & 0.119 & 0.545 & 0.745 & 0.386 & -0.246 & 0.303 \\
\hline Vruckwona (P2) & -0.036 & 0.058 & 0.153 & 0.740 & 0.475 & -1.202 & 0.055 & -0.620 & -0.610 & -0.467 & 0.021 & -0.149 \\
\hline Pusa Napier No. 2 (P3) & -0.063 & 0.066 & -0.086 & -3.217 & -3.255 & -0.642 & -0.001 & 0.338 & -0.029 & 0.169 & 0.322 & -0.240 \\
\hline Porto Rico 534-B (P4) & 0.901 & 0.192 & -0.008 & 3.007 & 3.282 & 0.414 & -0.173 & -0.263 & -0.106 & -0.088 & -0.097 & 0.086 \\
\hline Mercker Santa Rita (P5) & -0.014 & -0.099 & 0.043 & 0.125 & -0.653 & -0.936 & -0.022 & -0.144 & -0.223 & -0.719 & 0.034 & -0.089 \\
\hline Taiwan A-146 (P6) & 0.028 & -0.015 & 0.012 & -1.610 & 1.166 & -0.087 & -0.039 & -0.408 & -0.324 & -0.256 & -0.053 & -0.102 \\
\hline Mercker S. E. A. (P7) & 0.006 & -0.007 & 0.033 & 1.023 & 0.432 & 0.194 & 0.144 & 0.148 & -0.047 & -0.063 & 0.150 & -0.039 \\
\hline Napier No. 2 (P8) & -0.020 & 0.121 & -0.087 & 0.462 & -0.944 & 0.829 & -0.083 & 0.404 & 0.594 & 0.390 & -0.130 & 0.229 \\
\hline
\end{tabular}

Male genitors: Taiwan A-144 (P1), Vruckwona (P2), Pusa Napier No. 2 (P3) and Porto Rico 534-B (P4); female genitors: Mercker Santa Rita (P5), Taiwan A-146 (P6), Mercker S. E. A. (P7) and Napier No. 2 (P8). HGT = plant height $(\mathrm{m}) ; \mathrm{SD}=$ stem diameter $(\mathrm{mm}) ; \mathrm{LBW}=$ leaf blade width $(\mathrm{cm}) ; \mathrm{NT}=$ number of tillers per linear meter; $\mathrm{DMP}=$ dry matter production $(\mathrm{t} / \mathrm{ha}) ; \% \mathrm{DM}=$ percentage of dry matter; $\% \mathrm{ASH}=$ percentage of ash; $\% \mathrm{NDF}=$ percentage of neutral detergent fiber; $\% \mathrm{ADF}=$ percentage of acid detergent fiber; $\% \mathrm{CEL}=$ percentage of cellulose; $\% \mathrm{HEM}=$ percentage of hemicellulose; $\% \mathrm{LIG}=$ percentage of lignin.

The parents showing positive values for SD included Porto Rico 534-B and Napier No. 2, with values of 0.192 and 0.121 , respectively. For the HGT trait, parent Porto Rico 534B showed the highest estimate for SD.

For leaf-blade width, the Vruckwona parent showed a positive value of 0.153 . For the number of tillers, the parents with positive values included Vruckwona, Porto Rico 534-B, 
Mercker S. E. A., and Napier No. 2, with values of 0.740, 3.007, 1.023, and 0.462, respectively. DMP is one of the most important characteristics of elephant grass evaluated in this study. For DMP, some parents showed positive values. Among the males, parents Rico 534B and Vruckwona showed the highest DMP values of 3.282 and 0.475 , respectively. Among females, Taiwan A-146 and Mercker S. E. A. showed values of 1.166 and 0.432 , respectively. Once again, parent Porto Rico 534-B showed the highest positive estimate among all parents.

In terms of \%DM, the negative values of the estimate for the GCA effects were of primary concern, as these values indicate DMP gains in breeding programs. In this case, the parent Vruckwona showed the highest estimate of -1.202 , followed by Mercker Santa Rita with a value of -0.936 and Pusa Napier No. 2 with a value of -0.642 . As previously discussed, parents Vruckwona and Taiwan A-146 showed positive GCA values for the DMP trait. The parents Vruckwona, Porto Rico 534-B, Taiwan A-146, and Mercker S. E. A. are the most promising, as they contribute to an increased frequency of favorable genes for DMP.

For traits $\% \mathrm{NDF}, \% \mathrm{ADF}, \% \mathrm{CEL}, \% \mathrm{HEM}$, and $\% \mathrm{LIG}$, and considering the genetic gain for DMP associated with biomass-quality traits, for the \%NDF variable, Mercker S. E. A. was the only parent to present a positive value (0.148). Neither \%ADF nor \%CEL exhibited positive values. For \%HEM, parents Vruckwona and Mercker S. E. A., with values of 0.150 and 0.021 , respectively, were the only genotypes with positive estimates. Finally, for \%LIG, the parent Porto Rico 534-B had a value of 0.086 .

Estimates for SCA effects $\left(\hat{s}_{j}\right)$ for the morpho-agronomic and biomass-quality traits assessed in 16 hybrid combinations, resulting from the diallel crosses of 8 parents of elephant grass, are shown in Table 4. For the HGT trait, the hybrid combinations showing the highest positive estimates were $1 \times 5$ (0.103), 2 × 6 (0.078), $3 \times 7$ (0.111), and 4 × 5 (0.061). These combinations included at least one of the parents with positive value of $g_{i}$ or $g_{j}^{\prime}$.

The SD values verified that the best hybrid combinations and respective estimates were $1 \times 5$ (0.612), 1 × 6 (0.110), 1 × 7 (0.251), 2 × 7 (1.278), 3 × 6 (1.043), $3 \times 7$ (1.102), and $3 \times 8$ (0.243). The estimates of GCA were not significant in any of the groups (Table 2).

Positive estimates of GCA for SD in group 1 (male parents) were observed among the parents Porto Rico 534-B, Pusa Napier No. 2, and Vruckwona, with values of 0.193, 0.066, and 0.058 , respectively (Table 3 ). In group 2 (female parents), the highest estimate was observed for parent Napier No. 2, with a value of 0.121 (Table 3). Because the best hybrid combinations should be those with the highest $\hat{s}_{\bar{j}}$, with parents showing GCA (Cruz and Regazzi, 1997), it can be inferred that the best hybrid combination and respective $\hat{s}_{\dot{j}}$ were $3 \times 8(0.243)$, in which the 2 parents showed favorable effects for GCA, followed by the hybrid of highest $\hat{s}_{j}, 2 \times 7$ (1.278), and hybrids $3 \times 6$ (1.043), $3 \times 7$ (1.102), in which at least 1 of the parents had a positive GCA estimate.

Reduced, but positive estimates of $\hat{s}_{i j}$ were obtained for the LL trait. Of the 10 positive estimates of $\hat{s}_{i j}$ (Table 4), 3 had at least 1 parent with a high GCA, as follows: $3 \times 6(0.409), 3 \times$ 7 (0.236), and 4 x $6(0.441)$.

Seven hybrid combinations had positive $\hat{s}_{\boldsymbol{j}}$ values for NT (Table 4 ) and had at least 1 parent with an elevated GCA value. These combinations and their respective $\hat{s}_{\boldsymbol{j}}$ values were $1 \times 5$ (8.259), 1 × 7 (6.915), 1 × 8 (4.365), 2 × 6 (12.030), 3 × 7 (8.720), 3 × 8 (13.089), and 4 × 5 (2.017).

DMP, which is the most important trait of the culture, showed the highest positive estimates of $\hat{s}_{i j}$ for hybrids $1 \times 5$ (5.024), 1 × 8 (3.064), 2 × 6 (5.317), $3 \times 7$ (8.057), and 4 × 5 (0.329). As to the biomass-quality traits, hybrids $1 \times 5,1 \times 7,2 \times 6,2 \times 8,3 \times 5,3 \times 7,4 \times 6$, and $4 \times 8$, stood out, with the best estimates of $\hat{s}_{j}$ for the $\% \mathrm{DM}$ variable. 
Table 4. Estimates of the effects of specific combining ability $\left(\hat{s}_{i}\right)$, for the morpho-agronomic and biomassquality traits assessed in 16 hybrid combinations resulting from the partial diallel crosses among 8 types of elephant grass genotypes. Campos dos Goytacazes, RJ. 2011/2012.

\begin{tabular}{|c|c|c|c|c|c|c|c|c|c|c|c|c|}
\hline \multirow[t]{2}{*}{ Effects (siji) } & \multicolumn{12}{|c|}{ Characteristics } \\
\hline & HGT & SD & LBW & NT & DMP & $\% \mathrm{DM}$ & $\% \mathrm{ASH}$ & $\% \mathrm{NDF}$ & $\% \mathrm{ADF}$ & $\% \mathrm{CEL}$ & $\%$ HEM & $\%$ LIG \\
\hline $1(1 \times 5)$ & 0.103 & 0.612 & -0.116 & 8.259 & 5.024 & 2.323 & -0.325 & -0.356 & -0.239 & -0.353 & -0.088 & 0.104 \\
\hline $\mathrm{H} 2(1 \times 6)$ & -0.172 & 0.110 & 0.019 & -4.006 & -5.634 & -0.616 & 0.145 & -0.340 & -0.776 & -0.918 & 0.390 & 0.102 \\
\hline H3 (1x7) & -0.078 & 0.251 & 0.044 & 6.915 & -3.757 & 0.946 & -0.144 & 0.116 & 0.177 & -0.141 & -0.031 & 0.064 \\
\hline $\mathrm{H} 4(1 \times 8)$ & -0.079 & -0.008 & -0.135 & 4.365 & 3.064 & -0.584 & 0.207 & -0.505 & -0.679 & -0.198 & 0.009 & -0.429 \\
\hline H5 $(2 \times 5)$ & -0.241 & -0.256 & -0.025 & -2.974 & -2.915 & -0.034 & 0.228 & 0.484 & 0.325 & 0.013 & 0.113 & 0.105 \\
\hline H6 (2x6) & 0.078 & -2.002 & -0.396 & 12.030 & 5.317 & 2.231 & -0.570 & 0.900 & 1.364 & 1.280 & 0.023 & 0.465 \\
\hline H7 $(2 \times 7)$ & 0.050 & 1.278 & -0.393 & -2.317 & 0.992 & -3.613 & 0.435 & -1.224 & -0.756 & -0.780 & -0.515 & 0.042 \\
\hline H8 (2x8) & -0.002 & -0.260 & -0.128 & -4.718 & -3.529 & 0.586 & -0.348 & 1.499 & 1.542 & 1.064 & -0.194 & 0.648 \\
\hline H9 $(3 \times 5)$ & -0.086 & -0.789 & -0.176 & 0.649 & -0.495 & 2.397 & -0.055 & -1.262 & -1.296 & -1.340 & 0.064 & -0.120 \\
\hline H10 (3x6) & -0.322 & 1.043 & 0.409 & -3.580 & -6.490 & -1.294 & 0.211 & -0.918 & -0.659 & -0.559 & -0.305 & -0.296 \\
\hline H11 $(3 \times 7)$ & 0.111 & 1.102 & 0.236 & 9.149 & 8.057 & 2.594 & 0.137 & 0.029 & -0.343 & -0.264 & 0.403 & -0.034 \\
\hline H12 (3x8) & -0.074 & 0.243 & -0.242 & 13.089 & 1.976 & -0.304 & 1.066 & -1.498 & -1.507 & -1.285 & -0.065 & -0.394 \\
\hline H13 (4x5) & 0.061 & -0.131 & -0.322 & 2.017 & 0.329 & -3.321 & 0.347 & 0.272 & 0.591 & 0.392 & -0.394 & 0.030 \\
\hline H14 (4x6) & -0.037 & -0.557 & 0.441 & -4.174 & -0.574 & 1.661 & 0.415 & -0.632 & -1.684 & -0.742 & 0.902 & -0.734 \\
\hline H15 (4x7) & -0.157 & -0.583 & -0.073 & -2.427 & -4.084 & -0.286 & 0.109 & -0.138 & -0.151 & -0.132 & -0.063 & -0.105 \\
\hline H16 (4x8) & 0.032 & -0.149 & 0.161 & 0.416 & -1.873 & 0.378 & 0.193 & -0.341 & 0.139 & 0.194 & 0.178 & -0.112 \\
\hline
\end{tabular}

Male genitors: Taiwan A-144 (P1), Vruckwona (P2), Pusa Napier No. 2 (P3) and Porto Rico 534-B (P4); female genitors: Mercker Santa Rita (P5), Taiwan A-146 (P6), Mercker S. E. A. (P7) and Napier No. 2 (P8). HGT = plant height $(\mathrm{m}) ; \mathrm{SD}=$ stem diameter $(\mathrm{mm}) ; \mathrm{LBW}=$ leaf blade width $(\mathrm{cm}) ; \mathrm{NT}=$ number of tillers per linear meter; $\mathrm{DMP}=$ dry matter production $(\mathrm{t} / \mathrm{ha}) ; \% \mathrm{DM}=$ percentage of dry matter; $\% \mathrm{ASH}=$ percentage of ash; $\% \mathrm{NDF}$ $=$ percentage of neutral detergent fiber; $\% \mathrm{ADF}=$ percentage of acid detergent fiber; $\% \mathrm{CEL}=$ percentage of cellulose; $\% \mathrm{HEM}=$ percentage of hemicellulose; $\% \mathrm{LIG}=$ percentage of lignin.

For $\% \mathrm{ASH}$, the crosses $1 \times 5,2 \times 6$, and $2 \times 8$ showed the highest negative effects of $\hat{s}_{j}:-0.325,-0.570$, and -0.848 , respectively.

The hybrid combinations showing the highest positive estimates of $\hat{s}_{\boldsymbol{j}}$ for $\% \mathrm{NDF}$ were 2 x 5 (0.484), 2 × 6 (0.900), 2 × 8 (1.499), and 4 × 5 (0.272) (Table 4).

For the estimates of SCA for \%ADF, the hybrid combinations with positive $\hat{s}_{j}$ values were 1 × 7 (0.177), 2 × 6 (1.364), 2 × 8 (1.542), 4 × 5 (0.591), and 4 × 8 (0.139).

The best results for \%ASH were shown by hybrids $2 \times 5,2 \times 6,2 \times 8,4 \times 5$, and $4 \times 8$, with respective positive values of $0.013,1.280,1.064,0.392$, and 0.194 . Based on the positive estimates of GCA of the parents Taiwan A-144 (0.386), Pusa Napier No. 2 (0.169), and Napier No. 2 (0.390), the best combinations were $2 \times 8$ and $4 \times 8$, as at least 1 of their parents displayed a positive GCA value.

\section{DISCUSSION}

The estimates of the GCA effects have a great utility for indicating parents that should be included in breeding programs because of the activity of predominantly active genes and their effects, allowing the relative importance of GCA to be compared for the various parents used (Falconer, 1987).

High positive GCA estimates indicate that the mean of crosses involving a particular parent is higher than the overall mean of $\mathrm{F}_{1}$ 's, which enters the crossing system. Low positive values indicate that the GCA value ability of the parents does not differ from the overall mean of the diallel crosses. In contrast, negative values, either high or low, indicate that the parent contributes negatively to the gains relative to the characteristics being examined (Cruz and Regazzi, 1997). 
In elephant-grass breeding programs aimed at generating energy, the final goal is to obtain materials with greater positive values estimated for the effects of the GCA of plant DMP, SD, leaf blade width, number of tillers per linear meter (NT), percentage of \%NDF, percentage of $\% \mathrm{ADF}$, and $\% \mathrm{LIG}$, as the main target is energy generation.

Evaluating a partial diallel of elephant grass in the city of Campos dos Goytacazes, Brazil, Silva (2011) analyzed the same groups of parents and obtained the following estimates for the GCA effect: for height, the best results were found for the parents A-144, Pusa Napier No. 2, and Taiwan A-146, of 3.764, 1.662, and 13.125, respectively. For stem diameter, the values were too low, not exceeding 0.039 , while for leaf blade width, only the parents Vruckwona and Napier No. 2 showed positive values: 4.094 and 2.124, respectively. In addition, these same parents presented positive values, 0.697 and 0.414 , for DMP, respectively.

Analyzing the morpho-agronomic traits by diallel crosses between elephant grass and pearl millet, Pereira et al. (2006) observed that the $\hat{\mathrm{g}}_{\mathrm{i}}$ estimates obtained for traits related to DMP showed elevated magnitudes because of the predominant influence of the parents on the additive genetic effects related to these traits in elephant grass. These authors also verified that the BAG parents (e.g. accessions BAG-75, BAG-19, BAG-27, and BAG-64) are promising for obtaining cultivars from intraspecific breeding programs.

Thus, estimates for the effects of GCA allowed identification of promising parents. Thus, the 2 groups of male and female parents showed different behaviors in relation to morpho-agronomic traits and biomass quality. Among those showing the best GCA values for the morpho-agronomic traits HGT, SD, NT, and DMP was the parent Porto Rico 534-B, and for the morpho-agronomic traits LL, SD, NT, and DMI was the parent Vruckwona. Taiwan A-144 and Napier No. 2 showed positive estimates for biomass quality traits, meaning that they can contribute to increased biomass quality in breeding programs.

Falconer (1987) defined SCA as the deviation of the average performance of a particular combination compared to the average value of the parents involved in the cross. Thus, low positive or negative estimates of $\left(\hat{s}_{\boldsymbol{j}}\right)$ indicate that hybrids behaved as expected based on the GCA of their parents, while high absolute values of $\left(\hat{s}_{j}\right)$ indicated that some combinations were relatively better and others worse, based on the parental GCA values (Sprague and Tatum, 1942; Cruz et al., 2004).

Moreover, the estimate of the effect of GCA is defined as the measurement of the nonadditive genetic effect, and so it is interest of the breeder in the hybrid combinations with the best estimates of SCA involving at least 1 of the parents with favorable estimates for the effect of GCA (Cruz et al., 2004). Importantly, 2 parents with high GCA do not always form the best diallel combination (Cruz and Vencovsky, 1989).

Therefore, SCA estimates for the DMP trait confirm the potential of the combinations $1 \times 5,2 \times 6,3 \times 7$, and $4 \times 5$, which showed the best results for other morpho-agronomic characteristics. Among these combinations, hybrid 2 x 6 showed the best estimates for SCA of 5.317, as well as positive estimates of GCA for their parents (Table 3). However, some of the hybrids with the highest DMP averages did not always show positive SCA values, such as combinations $4 \times 6$, with an average of $24.91 \mathrm{t} /$ ha and $\hat{s}_{j}$ of -0.574 ; and $4 \times 8$, averaging 21.50 $\mathrm{t} /$ ha and $\hat{s}_{j}$ of -1.873 . Thus, the best hybrid combinations were $2 \times 6(5.317)$ and $2 \times 7(0.992)$, followed by the hybrid with the highest $\hat{s}_{i}, 3 \times 7$ (8.057).

Among the biomass-quality traits, Pereira et al. (2000) found that the dry matter content in elephant grass is affected not only by plant age, but also by leaf emission rate. Thus, breeding programs should consider both the genetic differences affecting dry matter content 
and the composition of this dry matter.

One of the traits that should be considered when selecting material for energy production by direct combustion is \% ASH, as this quality influences the operational characteristics of conversion of biomass to energy (McKendry, 2002). In this context, \%ASH is linearly opposite to the percentage of organic matter, and thus the interest in hybrid combinations with negative values, as they indicate the capacity of the hybrid to express the dry matter fraction and do not reflect greater calorific power.

In this study, we found that for \%NDF, because GCA was not significant $(\mathrm{P}>0.05)$ for the parents from group 2 (female parents) (Table 2) and the highest positive GCA estimates for group 1 (male genitors) occurred for parents Taiwan A-144 (0.545) and Pusa Napier No. $2(0.338)$ (Table 3 ), the best hybrid combinations and respective estimates of $\hat{s}_{j}$ were $1 \mathrm{x} 7$ (0.116), and $3 \times 7$ (0.029), as for both combinations the parents had positive GCA values.

In addition, among the combinations that stood out for the \%ADF trait, combinations $2 \times 6$ and 4 x 5 did not meet the requirements proposed by Cruz and Regazzi (1997). Neither parent presented a favorable (positive) GCA effect. Therefore, the best hybrid combinations were $1 \times 7,2 \times 8$, and $4 \times 8$. Hybrid $2 \times 8$ was also selected for the traits \%NDF, \%CEL, and $\%$ LIG, supporting the potential of this hybrid combination for energy production. The disadvantages of this combination were the low mean values obtained for SD and LL (11.61 and 2.38 , respectively).

\section{CONCLUSIONS}

We characterized the involvement of additive genetic effects in the control of the evaluated traits. For morpho-agronomic traits such as HGT, LL, and DMP, as well as biomassquality traits such as $\% \mathrm{NDF}, \% \mathrm{ADF}, \% \mathrm{CEL}, \% \mathrm{HEM}$, and \%LIG, additive effects were observed only in the genotypes from group 1 (male parents).

Based on the better GCA values of the male parents compared to the female parents, genetic variability was observed among the male parents for both morpho-agronomic and biomass-quality traits.

The hybridization breeding strategy may be useful for optimizing traits important for energy production.

For the traits DMP, percentage of hemicellulose and percentage of lignin, for which no genetic effects were observed, there was no genetic variability among the hybrid combinations.

Parents Vruckwona, Porto Rico 534- B, and Taiwan A-146 are the most promising for integrating breeding programs, and they may contribute genetically to increased total DMP.

For the breeding programs aimed at improving the quality of the dry matter content, the parents Taiwan A-144 and Napier No. 2 are recommended.

The best hybrid combinations for DMP were 1 x 5 (Taiwan A-144 x Mercker Santa Rita), 1 x 8 (Taiwan A-144 x Napier no. 2), 2 x 6 (Vruckwona x Taiwan A-146), 3 x 7 (Pusa Napier No. 2 x Mercker S. E. A.), and 4 x 5 (Porto Rico 534-B x Mercker Santa Rita).

Crosses 2 x 6 (Vruckwona x Taiwan A-146) and 4 x 5 (Porto Rico 534-B x Mercker Santa Rita) showed the highest fiber content (\%NDF and \%ADF) in the dry matter.

\section{ACKNOWLEDGMENTS}

Research supported by Conselho Nacional de Desenvolvimento Científico e Tec- 
nológico $(\mathrm{CNPq})$ and Fundação Carlos Chagas Filho de Amparo à Pesquisa do Estado do Rio de Janeiro (FAPERJ). The authors thank CAPES, for granting the Master's fellowship; Universidade Estadual do Norte Fluminense Darcy Ribeiro and Programa de Pós-Graduação em Genética e Melhoramento de Plantas for the opportunity to attend the course; and Embrapa Gado De Leite and the laboratory of food analysis for conducting the biomass-quality analyses.

\section{REFERENCES}

Bennet HW (1976). Pasto Johnson, Pasto Alfombra y Otras Gramineas para El sur Humedo de los Estados Unidos. (Hugues HD, Heath ME and Metcalfe DS, eds.). Forrajes. C.E.C.S.A., Mexico. cap. 29: 321-334.

Cruz CD and Vencovsky R (1989). Comparação de alguns métodos de análise dialélica. Rev. Bras. Genet. Ribeirão Preto 12: 425-438.

Cruz CD and Regazzi AJ (1997). Modelos Biométricos Aplicados ao Melhoramento Genético. Universidade Federal de Viçosa, Viçosa.

Cruz CD, Regazzi AJ and Carneiro PCS (2004). Modelos Biométricos Aplicados ao Melhoramento Genético, 3rd edn. Editora Universidade Federal de Viçosa, Viçosa.

Cruz CD (2013). GENES - a software package for analysis in experimental statistics and quantitative genetics. Acta Sci. Agron. 35: 271-276.

de Lima RS, Daher RF, Goncalves LS, Rossi DA, et al. (2011). RAPD and ISSR markers in the evaluation of genetic divergence among accessions of elephant grass. Genet. Mol. Res. 10: 1304-1313.

Falconer DS (1987). Introduction to Quantitative Genetics. 2nd edn. Longman, London.

Ferraris R (1979). Agronomic Studies on Elephant Grass as an Agro-industrial Crop. In: Research Review - Division of Chemical Technology. Institute of Industrial Technology, Commonwealth Scientific and Industrial Research Organization, Melbourne, 10-22.

Finkner RE, Finkner MD, Glaze RM and Maese G (1981). Genetic control for percentage grain protein and grain yield in grain sorghum. Crop. Sci. 21: 139-142.

Freitas NS, de Arruda Falcão, Burity HA, Tabosa JN, et al. (2000). Caracterização e diversidade genética do capimelefante e seus híbridos com milheto mediante padrões isoenzimáticos. Pes. Agropec. Bras. 35: 1125-1133.

Geraldi IO and Miranda-Filho JB (1989). Adapted models for the analysis of combining ability of varieties in partial diallel crosses. Braz. J. Genet. 11: 419-430.

Griffing B (1956). Concept of general and specific combining ability in relation to diallel crossing systems. Aust. J. Biol. Sci. 9: 463-493.

McKendry P (2002). Energy production from biomass (Part 1): Overview of biomass. Bioresour. Technol. 83: 37-46.

Morais RF, de Souza BJ, Leite JM, de Barros Soares LH, et al. (2009). Elephant Grass genotypes for bioenergy production by direct biomass combustion. Pesq. Agropec. Bras. 44: 133-140.

Osava M (2007). Capim Elefante, Novo Campeão em Biomassa no Brasil. AgrosoftBrasil, Pereira. Available at [www. agrosoft.org.br/?q=node/26484]. Accessed July 20, 2013.

Pereira AV, Ferreira RP, Passos LP, Freitas VP, et al. (2000). Variação da qualidade de folhas em cultivares de capimelefante e híbridos de capim-elefante x milheto, em função da idade da planta. Cienc. Agrotec. 24: 490-499.

Pereira AV, Valle CB, Ferreira RP and Miles JW (2001). Melhoramento de Forrageiras Tropicais. In: Recursos Genéticos e Melhoramento de Plantas (Nass LL, Valois ACC, Melo IS and Valadares-Ingres MC, eds.). Fundação Mato Grosso, Rondonópolis, 549-602.

Pereira AV, Daher RF, Pereira MG, Ledo FJS, et al. (2006). Análise de cruzamentos dialélicos entre capim-elefante (Pennisetum purpureum Schum.) e milheto [Pennisetum glaucum (L.) R. Br.]. 1. Características morfoagronômicas. Acta Sci. Agron. 28: 267-275.

Queiroz Filho JL, Silva DS and Nascimento IS (2000). Produção de Matéria Seca e Qualidade do Capim-elefante (Pennisetum purpureum Schum.) cultivar Roxo, em diferentes idades de corte. Rev. Bras. Zootecnol. 29: 69-74.

Rossi DA (2010). Avaliação Morfoagronômica e da Qualidade da Biomassa de Acessos de Capim-Elefante (Pennisetum purpureum Schum.) para Fins Energéticos no Norte Fluminense. Master's thesis - Campos dos Goytacazes Universidade Estadual do Norte Fluminense.

Santos EA, Silva DS and Queiroz Filho JL (2001). Perfilhamento e algumas características morfológicas do capim-elefante cv. Roxo sob quatro alturas de corte em duas épocas do ano. Rev. Bras. Zootec. 30: 24-30.

Silva ALC, Santos MVF, Dubeux Júnior JCB, Lira MA, et al. (2010). Variabilidade e herdabilidade de caracteres 
morfológicos em clones de capim-elefante na Zona da Mata de Pernambuco. Rev. Bras. Zootec. 39: 2132-2140.

Silva MMP, Vasquez HM, da Silva JFC, Bressan-Smith RE, et al. (2002). Composição bromatológica, disponibilidade de forragem e índice de área foliar de 17 genótipos de capim-elefante (Pennisetum purpureum Schum.) sob pastejo, em Campos dos Goytacazes, RJ. Rev. Bras. Zootec. 31: 313-320.

Silva VQR (2011). Dialelo Parcial em Capim-elefante: Capacidade Combinatória em Caracteres Morfoagronômicos e Bromatológicos em Campos dos Goytacazes, RJ. Doctoral thesis, Universidade Estadual do Norte Fluminense Darcy Ribeiro, Campos dos Goytacazes.

Sprague GF and Tatum LA (1942). General vs specific combining ability in single crosses of corn. J. Am. Soc. Agron. 34: 923-932.

Urquiaga S, Alves BJR and Boodey RM (2005). Produção de biocombustíveis: a questão do balanço energético. Rev. Política Agrícola 14: 42-46.

Wilson ND, Weibel DE and McNew RW (1978). Diallel analyses of grain yield, percent protein, and protein yield in grain sorghum. Crop. Sci. 18: 491-495. 